\title{
Unnes Journal of Public Health
}

\author{
http://journal.unnes.ac.id/sju/index.php/ujph
}

\section{The Influence of Digestive Tract Length of Larvivorous Fish Related to Predation Potential on Aedes aegypti Larvae}

\section{Tri Baskoro Tunggul Satoto ${ }^{1 \bowtie}$, Dyah Mahendrasari Sukendra ${ }^{2}$, Ignatius Hardaningsih ${ }^{3}$, and Ajib Diptyanusa ${ }^{4}$}

${ }^{1}$ Center for Tropical Medicine, Universitas Gadjah Mada

${ }^{2}$ Department of Public Health, Faculty of Sport Science, Universitas Negeri Semarang

${ }^{3}$ Department of Fisheries, Faculty of Agriculture, Universitas Gadjah Mada

${ }^{4}$ Department of Parasitology, Faculty of Medicine, Public Health and Nursing, Universitas Gadjah Mada

\section{Article Info}

Article History:

Submitted Mei 2019

Accepted June 2019

Published July 2019

\section{Keywords:}

fish, predation, digestive

tract, aedes aegypti, larvae

\begin{abstract}
Background: Biological vector control by using larvivorous fish will be beneficial in reducing Aedes aegypti population, hence reducing risk of dengue virus transmission. It is important to select the larvivorous fish according to its digestive organ. Current study aimed to investigate the predation potential among the fish species and to identify the influence of the digestive tract length of the fish related to their predation potential.Methods :The research was an analytical observational study with post-test only design. Third stage larvae of Aedes aegypti were used as preys for tilapia (Oreochromis niloticus), common carper (Cyprinus carpio), and guppy (Poecillia reticulata). Results: In association with their digestive tract length, predation potential of tilapia, common carper, and guppy showed statistical differences $(P<0.05)$. Tilapia demonstrated highest predation of the larvae, followed by common carper and guppy. There are associations between difference in shapes of mouth and intestines, mouth width, intestinal length, and predation potential of these fish species. Current study results showed possible associations between digestive tract length of tilapia, common carper and guppy and predation potential on Aedes aegypti larvae, allowing these fish species to be used inbiological control of Aedes aegypti.
\end{abstract}

\section{INTRODUCTION}

Dengue Haemorraghic Fever (DHF) is caused by Dengue viruses and is transmitted by Aedes aegypti (WHO, 2012). Currently DHF is still classified as an important disease in public health, as this disease causes high mortality (Bhatt et al., 2013). To overcome and to eliminate DHF, reduction of Aedes aegypti population is an efficient and effective program to minimize potential outbreak of DHF (Chang et al., 2011). One of the methods to reduce burden of DHF is by vector control by reducing the number of larval stages of Aedes aegypti (Trewin et al., 2017).

Indonesian Ministry of Public Health suggested a program to overcome the DHF problem called the ' $3 \mathrm{M}$ Plus' $(\mathrm{MOH}, 2010)$. This program aims to drain water reservoirs, to bury thrifts that may act as potential water reservoirs, and to cover any kind of water reservoirs. Addition of larvicidal agents into those water reservoirs is also part of the ' $3 \mathrm{M}$ Plus' program. Meanwhile, chemical vector control method by using synthetic chemical insecticides causes negative impact such as development of insecticide resistance and may be potentially harmful to non-

C2019 Universitas Negeri Semarang

Center for Tropical Medicine, Universitas Gadjah Mada, PAU UGM Building,

Jalan Teknika Utara, Barek, Yogyakarta 55281, Indonesia. Phone +62 274588483.

pISSN 2252-6781

Fax +62274

eISSN 2584-7604

E-mail: tribaskoro@ugm.ac.id 
target populations (Bouzid et al., 2016). Residue of synthetic chemical insecticides is difficult to degrade, hence it may also cause harm to the ecosystem. Natural insecticides have been recently mentioned as substitutes for synthetic insecticides as these natural insecticides are easily broken down (Sritabutra \&Soonwera, 2013). Even so, the insecticidal effects of natural insecticides are generally short, so that the application needs to be repeated frequently (Trewin et al., 2017). One of the alternative methods to reduce mosquito vector of DHF is to use the biological vector control method by using larvivorous fish (Paiva et al., 2014; MOH, 2010).

A study reported that tilapia (Oreochromis niloticus) showed good larvae predation potential by being able to feed on 246 mosquito larvae for 24 hours, whereas common carp (Cyprinus carpio) could feed on 148 mosquito larvae for 24 hours (Bibi et al., 2017; Sheetal \& Shate, 2015). Another study demonstrated that guppy (Poecilla reticullata) also showed a good predation potential, as this species could feed on 47 mosquito larvae for 6hours (Mutmainah et al., 2014). Therefore, tilapia, common carper, and guppy had demonstrated benefit in vector control. These fish species may be chosen as biological vector control in permanent and semi-permanent aquatic habitats.However, problems arose when the water became dirty due to their excretory products. Such water problem can be minimized by selecting proper and efficient species of larvivorous fish.

Current study aimed to investigate the predation potential among the fish species and to identify the influence of the digestive tract length of the fish related to their predation potential. The presence of larvivorous fish in the natural breeding places of mosquitoes triggered multiple interactions and impacts not only to the organisms themselves, but also to the environment. As the association between digestive tract anatomies of larvivorous fish with their predation potential is poorly understood, a study about differences in larvae predation potential of larvivorous fish in association with their digestive tract organs is necessary in order to select appropriate species in biological vector control. Current study results can also be used as supporting data in the policy formulation in DHF vector control.

\section{METHODS}

The research was an analytical observational study with post-test only design. Approval to conduct the research was given from the Faculty of Medicine, Universitas Gadjah Mada (Reference no. UGM/KU/Prst/057/M/05/07). Larvivorous fish species used in the research were tilapia (Oreochromis niloticus), common carper (Cyprinus carpio), and guppy (Poecillia reticulata) aged 3-4 weeks. The fish were obtained from local fish market in Yogyakarta, Indonesia and were brought to the laboratory. The body length of tilapia, common carper, and guppy were measured from the tip of the mouth to the end of the body, excluding the caudal fin. Live and healthy $3^{\text {rd }}$ stage larvae of Aedes aegypti were used as preys to observe the predation potential of larvivorous fish. The research started on 3 April 2014 and ended on 19 June 2014.

The fish were quarantined for one week before the research started to allow matching process: to obtain similar fish condition and stomach contents (Vinson \& Angradi, 2011). Environmental temperature and humidity, as well as water temperature were recorded during the study. The fish were fed once daily in the early morning and feeding stopped at 24 hours before the research started in order to empty the fish stomach. Fish were divided into three groups: Group 1, consisted of 5 tilapias;Group 2, consisted of 5 common carpers; and Group 3, consisted of 5 guppies. Each fish in each group was put in one tank (diameter of $10 \mathrm{~cm}$ and depth of $15 \mathrm{~cm}$, filled with 11 of water), and into each tank was given $2003^{\text {rd }}$ stage larvae of Aedes aegypti. The reduction in number of larvae was noted at 1 hour, 6 hour, 12 hour, 18 hour, and 24 hour. Interventions in each subgroup were performed in 3 replications. $\mathrm{R}$ e duction in number of larvae, or predation potential, was calculated from the following formula (Cowan and Houde 1993):

$$
\mathrm{P}=((\mathrm{U}-\mathrm{M})) / \mathrm{n}
$$

$\mathrm{P}=$ reduction in number of larvae (predation potential)

$\mathrm{U}=$ total number of larvae fed by larvivorous fish

$\mathrm{M}=$ number of remaining larvae

$\mathrm{n}=$ number of larvivorous fish tested

Data analysis was performed using SPSS ver.17 (SPSS Inc., USA). Feeding rate (predation potential) was analyzed by using one-way ANOVA and Least Significant Difference (LSD) analysis in order to compare the feeding rate on Aedes aegypti larvae of tilapia, common carper, and guppy with the density of larvae. The predation potential was analyzed from data obtained in 1 hour, 6 hour, 12 hour, 18 hour, and 24 hour. Level of significance used for statistical analysis was $\mathrm{P}<0.05$.

\section{RESULTS AND DISCUSSION}

In current study, tilapia had average body length of $2.68 \pm 0.13 \mathrm{~cm}$, whereas common carper had average body length of $2.50 \pm 0.16 \mathrm{~cm}$, and guppy had average body length of $2.53 \pm 0.15 \mathrm{~cm}$. Tilapia showed the highest average of body length, body 
Table 1. Characteristics of body length, body weight, mouth width, larvae-mouth width ratio, and intestinal length of tilapia (Orechromis niloticus), common carper (Cyprinus carpio), and guppy (Poecillia reticulate).

\begin{tabular}{lllll}
\hline $\begin{array}{l}\text { Character- } \\
\text { istics }\end{array}$ & Unit & $\begin{array}{l}\text { Tilapia (Orechromis } \\
\text { niloticus) }\end{array}$ & $\begin{array}{l}\text { Common carper } \\
\text { (Cyprinus carpio)* }\end{array}$ & Guppy (Poecillia reticulata)* \\
\hline Body length & $\mathrm{cm}$ & $2.68 \pm 0.13$ & $2.50 \pm 0.16$ & $2.53 \pm 0.15$ \\
\hline Body weight & $\mathrm{g}$ & $0.62 \pm 0.04$ & $0.29 \pm 0.06$ & $0.28 \pm 0.04$ \\
\hline $\begin{array}{l}\text { Mouth } \\
\text { width }\end{array}$ & $\mathrm{cm}$ & $0.04 \pm 0.3$ & $0.1 \pm 0.08$ & $0.25 \pm 0.05$ \\
\hline $\begin{array}{l}\text { Larvae- } \\
\text { mouth } \\
\text { width ratio }\end{array}$ & larvae/cm & $390 \pm 23.6$ & $1,022 \pm 49.7$ & $237 \pm 45.1$ \\
\hline $\begin{array}{l}\text { Intestinal } \\
\text { length }\end{array}$ & $\mathrm{cm}$ & $10.37 \pm 1.08$ & $3.28 \pm 0.75$ & $4.27 \pm 0.38$ \\
\hline
\end{tabular}

\section{*shown in mean $\pm \mathrm{SD}$}

weight, and intestinal length compared to common carper and guppy (Table 1).

On the other hand, common carper demonstrated the highest average of mouth width and larvae-mouth width ratio compared to the other two species. However, none of these differences demonstrated statistical significance. Macroscopic appearances of tilapia, common carper, and guppy used in the study were illustrated in Figure 1. The average environment humidity during the research was $74.44 \pm 0.72 \%$, while average water temperature was $27.5 \pm 0.43^{\circ} \mathrm{C}$.

Larvae density reduction of Aedes aegypti larvae (predation potential) in current study showed difference on each tilapia, common carper, and guppy in each period of observation. Feeding observation time at 1 hour showed that tilapia could feed more on Aedes aegypti larvaecompared to common carper and guppy (Table 2).

There was a statistically significant difference $(p<0.05)$ observed in predation among the fish species at 1 hour of observation.As described in Table 2. predation potential of tilapia showed a dramatic decrease at 6 hours of feeding observation time. Predation potential by common carper and guppy showed decrease as well. Statistical significance was observed in the predation difference $(p<0.05)$.

On the other hand, feeding observation time at 12 hours showed that tilapia and common carper revealed similar predation potential, whereas guppy demonstrated lower predation potential. However, the predation potential among the three species did not show significant difference. At 18 hours, both common carper and guppy showed decreasing ability in predation. Interestingly, tilapia demonstrated increasing predation potential compared to that of previous observation time (Table 2). These differences were statistically significant $(P<0.05)$. Feeding observation time at 24 hour showed that tilapia had reduced predation on Aedes aegypti larvae, while common carper and guppy exhibited constant predation potential. The predation differences among three fish species have proven statistical significance.

In general, predation potential analyzed using LSD method showed that average feeding rate of guppy showed lower results compared to those of tilapia and common carper. Tilapia demonstrated highest average feeding rate on $3^{\text {rd }}$ stage larvae of $\mathrm{Ae}$ des aegypti at all observation time.

Natural characteristics of larvivorous fish to feed on preys is essential to be applied as biological vector control agent to reduce the population of $\mathrm{DHF}$ vector. Mosquito predators as a biological control for the aquatic larval stage of mosquitoes. Parallel to current study results, several other studies showed that tilapia demonstrated promising predation potential against Aedes aegypti and Culex quinquefasciatus larvae (Bibi et al., 2017; Louca et al., 2009; Benelli et al.,2016). Common carp and guppies have also been reported to be natural biological vector control against Aedes aegypti, Aedes albopictus or Culex quinquefasciatus(Sanyal \& Ghosh, 2014; Saleeza et al.,2014, Londhe \& Sathe, 2015).

Predation potential in association with sex of tilapia, common carper, and guppy was not studied, as it was difficult to distinguish sex based on the morphology of younger fish. Rebensburg mentioned that sex of fish did not influence fish behavior, and that feeding behavior of fish correlated with sensory stimulation to the preys (Rebensburg, 2010). Predation potential of fish is the capability of fish to feed on preys. In current research, $3^{\text {rd }}$ stage larvae of Aedes aegypti were used as natural preys for tilapia, common carper, and guppy. Daily food intake of fish depends on their aggressiveness. Smaller fish may act more aggressively than the big ones 


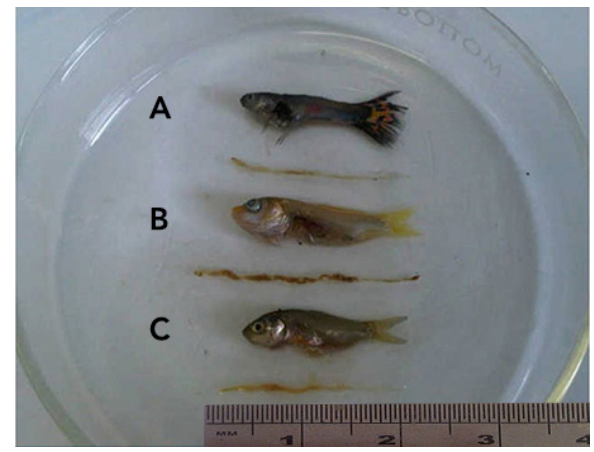

Figure 1. Comparison of macroscopic appearances of guppy (A), tilapia (B), and common carper (C).

to get food. Additionally, younger fish seek for food more frequently than mature fish in order to meet their growth demand (Lall \& Tibbetts, 2009; Martin et al., 2010; Sahtout et al., 2018; Manon \& Hossain, 2011)growth, and efficiency in juvenile tilapia (Oreochromis niloticus).

Smaller fish demonstrated lower predation potential compared to that of bigger fish (Novaes \& Carvalho, 2012). Mini tanks used in current study were possibly too small, containing only 11 of water, hence easier for smaller fish to feed on preys than bigger fish. Additionally, it was easier for the fish in current study to feed on the larvae due to frequent visual of larvae, as visual stimulation influences feeding behavior of fish (Rebensburg, 2010).

Size of larvae may have impact on the amount of larvae fed by fish. In regard to mouth width and stomach size, containment of mature, bigger larvae will be more difficult (Liew et al., 2012). Commonly, fish that are always feed on tiny preys usually have small stomach. Several species of fish, such as tilapia, can expand their stomach size, allowing them to feed on more preys. However, increasing frequency of feeding will reduce the aggressiveness of fish, hence reducing the amount of preys fed (Vinson \&Angradi, 2011; Sahtout et al., 2018; Shafi et al., 2012). This is demonstrated in current study results, that the numbers of larvae ingested by fish were generally decreasing over time.

Compared to those of common carper and guppy, current study demonstrated that tilapia had bigger size in body length, body weight, and intes-

Table 2.LSD of feeding rate of tilapia (Orechromis niloticus), common carper (Cyprinus carpio), and guppy (Poecillia reticulate) as predators of Aedes aegypti observed at 1 hour, 6 hour, 12 hour, 18 hour, and 24 hour.

\begin{tabular}{llll}
\hline Time & Species & Average predation & LSD (a=0.05) \\
\hline 1 Hour & Orechromis niloticus & $114^{\mathrm{b}}$ & 72.94 \\
& Cyprinus carpio & $40^{\mathrm{a}}$ & \\
& Poecillia reticulata & $36^{\mathrm{a}}$ & 17.91 \\
\hline 6 Hours & Orechromis niloticus & $19^{\mathrm{a}}$ & \\
& Cyprinus carpio & $18^{\mathrm{a}}$ & \\
& Poecillia reticulata & $12^{\mathrm{a}}$ & 15.91 \\
\hline 12 Hours & Orechromis niloticus & $21^{\mathrm{b}}$ & \\
& Cyprinus carpio & $20^{\mathrm{b}}$ & \\
& Poecillia reticulata & $4^{\mathrm{a}}$ & \\
\hline \multirow{1}{*}{ 18 Hours } & Orechromis niloticus & $47^{\mathrm{b}}$ & \\
& Cyprinus carpio & $7^{\mathrm{a}}$ & \\
& Poecillia reticulata & $3^{\mathrm{a}}$ & \\
\hline 24 Hours & Orechromis niloticus & $28^{\mathrm{b}}$ & \\
& Cyprinus carpio & $7^{\mathrm{a}}$ & \\
& Poecillia reticulata & $3^{\mathrm{a}}$ & \\
\hline
\end{tabular}

a-a $: \mathrm{I}\left(\mathrm{x}_{1}-\mathrm{x}_{2}\right) \mathrm{I} \leq \mathrm{LSD} \alpha=$ not significantly different

$\mathrm{a}-\mathrm{b}: \mathrm{I}\left(\mathrm{x}_{1}-\mathrm{x}_{2}\right) \mathrm{I} \geq \mathrm{LSD} \alpha=$ significantly different 
tinal length. This might explain higher predation potential of tilapia contrasted to other fish species. Bigger body size and larger stomach may contain more preys (Khojasteh, 2012, Hernandez et al., 2009; Raji \& Norouzi, 2010).Additionally, tilapia showed significantly higher number of larvae ingested during the first few hours of observation. As the stomach filled, the feeding rate decreased in all species.

Fish show rhythms of feeding and select their food as well. Fish seek for food according to their feeding rhythms at certain times of the day: at daylight or at nighttime. Fish show an inter-specific and intra-specific interaction regarding feeding behavior in each phase of their lives. In general, tilapia, common carper, and guppy feed on preys at daylight. However, current study results demonstrated that at each time of observation, the number of larvae has always been reduced. This showed flexibility of feeding rhythm, a good characteristic as biological vector control agents. Feeding behavior of fish resulted from responses to environment factors, including light, water condition, amount of preys, temperature, dissolved oxygen, and combinations of these factors (Luchiari \& Freire, 2009; Carvalho et al., 2013; Novaes \& Carvalho, 2012)

A proper selection and application of larvivorous fish as biological vector control to reduce the population of Aedes aegypti should be further introduced to society in order to reduce and to control DHF vector. According to current research results, tilapia (Orechromis niloticus) demonstrated promising results as the agent for biological vector control program.

\section{CONCLUSION}

There were significant differences in predation potential of tilapia, common carper and guppy against $3^{\text {rd }}$ stage larvae of Aedes aegypti. Measurements of digestive tract length showed differences between tilapia, common carper, and guppy. There were possible associations between digestive tract length of tilapia, common carper and guppy and predation potential on Aedes agypti larvae.

\section{Acknowledgements}

The authors would like to give appreciation to the staff of Laboratory of Parasitology, Faculty of Medicine, Public Health and Nursing, Universitas Gadjah Mada for all the assistance given throughout the study.

\section{REFERENCES}

Benelli, G., Jeffries, C.L., \& Walker, T. 2016. Biological Control of Mosquito Vectors : Past, Present, and Future. Journal of Insects, 7(4):52.

Bhatt, S., Gething, P.W., Brady, O.J., Messina, J.P., Farlow,
A.W., Moyes, C.L., Drake, J.M., Brownstein, J.S., Hoen, A.G., Sankoh. O et al., 2013. The Global Distribution and Burden of Dengue. Nature, 496(7446):504-7.

Bibi, S., Qayyum, M., Naseem, A., Khan, D., Ali S., Samiur-rehman, M., Aslam, M.R., \& Kassi A.K. 2017. Evaluation of Wild Tilapian and Gift Tilapia as Biological Control Against Mosquito Larvae (Culex quinquefasciatus and Aedes aegypti). International Journal of Mosquito Research, 4(1):23-27.

Bouzid, M., Brainard, J., Hooper, L., Hunter, P.R. 2016. Public Health Interventions for Aedes Control in the Time of Zikavirus- A Meta-Review on Effectiveness of Vector Control Strategies. PLoS Negl Trop Dis, 10(12):e0005176.

Carvalho. T.B., Mendonça, F.Z., Costa-Ferreira, R.S., Gonçalves-de-Freitas, E. 2013. The Effect of Increased Light Intensity on The Aggressive Behavior of The Nile Tilapia, Oreochromis niloticus (Teleostei: Cichlidae). Zoologia (Curitiba Impresso), 30(2):125-129

Chang, M.S., Christophel, E.M., Gopinath, D., Abdur, R.M., Malaria, Vectorborne O, Diseases P, World Health Organization Regional O, Western P. 2011. Challenges and Future Perspective for Dengue Vector Control in The Western Pacific Region. Western Pac Surveill Response Journal, 2(2):9-16.

Fortes-Silva, R., Martínez, F.J., Villarroel, M., SánchezVázquez, F.J. 2010. Daily Rhythms of Locomotor Activity, Feeding Behavior and Dietary Selection in Nile Tilapia (Oreochromis niloticus). Comp Biochem Physiol A Mol Integr Physiol, 156(4):445450.

Hernandez, D.R., Parez, G.M.,\& Domitrovic, H.A. 2009. Morphology, Histology and Histochemistry of The Digestive System of South American Catfish. International Journal of Morphology, 27: 105-111.

Khojasteh, S.M.B. 2012. The Morphology of The PostGastric Alimentary Canal in Teleost Fishes: ABrief Review. International Journal of Aquatic Science, 3(2): 70-88.

Lall, S. \& Tibbetts S.M. 2009. Nutrition, Feeding, and Behavior of Fish. Veterinary Clinics of North America Exotic Animal Practice, 12(2):361-72.

Liew, H.J., Sinha, A.K., Mauro, N., Diricx, M., Blust, R., De Boeck G. 2012. Fasting Goldfish, Carassius auratus, and Common Carp, Cyprinus carpio, Use Different Metabolic Strategies When Swimming. Comp Biochem Physiol A Mol Integr Physiol, 163(3-4):327-35.

Londhe, S. \& Sathe, T.V. 2015. Mosquito Larvae Consumption Rate of Cyprinus carpio L.Under Laboratory Conditions for Biological Pest Control. Indian Journal of Applied Research, 5(3):562-563.

Louca, V., Lucas, M.C., Green, C., Majambere, S., Fillinger, U., Lindsay, S.W. 2009. Role of Fish as Predators of Mosquito Larvae on the Floodplain of the Gambia River. J Med Entomol, 46(3):546-556.

Luchiari, A.C. \& Freire, F. 2009. Effects of Environmental Colour on Growth of Nile Tilapia, Oreochromis niloticus (Linnaeus, 1758), Maintained Individually or In Groups. Journal of Applied Ichthyology, 25:162-167. 
Manon, M. R., Hossain, M. D. 2011. Food and Feeding Habit of Cyprinus carpio var. specularis. Journal of Science Foundation, 9(1\&2):163-181.

Martin, C.W., Valentine, M.M., Valentine, J.F. 2010. Competitive Interactions between Invasive Nile Tilapia and Native Fish: The Potential for Altered Trophic Exchange and Modification of Food Webs. Plos One, 5(12):e14395.

$\mathrm{MOH}$ [Ministry of Health of Republic of Indonesia]. 2010. Prevention and Elimination of Dengue Hemorrhagic Fever in Indonesia. Jakarta: Ministry of Health Republic of Indonesia. p. 2-6.

Mutmainah, S., Prasetyo, E., \& Sugiarti, L. 2014. Daya Predasi Ikan Cupang (Betta splendens) dan Ikan Guppy (Poecilia reticulate) Terhadap Larva Instar III Nyamuk Aedes aegypti Sebagai Upaya Pengendalian Vektor Penyakit Demam Berdarah Dengue (DBD). Jurnal Sains Natural, 4(2) : 98-106.

Novaes, J.L., Carvalho, E.D. 2012. Reproduction, Food Dynamics and Exploitation Level of Oreochromis niloticus (Perciformes: Cichlidae) from Artisanal Fisheries in Barra Bonita Reservoir, Brazil. Rev Biol Trop, 60(2):721-34.

Paiva, C.N., Lima, J.W., Camelo, S.S., Lima, Cde. F., Cavalcanti, L.P. 2014. Survival of Larvivorous Fish Used for Biological Control of Aedes aegypti (Diptera: Culicidae) Combined With Different Larvicides. Trop Med Int Health, 19(9):1082-6.

Raji, A.R.\&Norouzi, E. 2010. Histological and Histochemical Study on The Alimentary Canal in Walking Catfish (Claris batrachus) and Piranha (Serrasalmusnattereri). Iranian Journal Veterinary Research, 3: $255-261$.

Rebensburg, P. 2010. Assessment and evaluation of temperament traits in carp (Cyprinus carpio L.), with contrasts between mirror and scaled morphological phenotypes. Undergraduate Thesis. Berlin: Free University of Berlin.

Saleeza, S.N., Norma-Rashid, Y., Sofian-Azirun, M. 2014.
Guppies as Predators of Common Mosquito Larvae in Malaysia. Southeast Asian J Trop Med Public Health, 45(2):299-308.

Sahtout, F., Boualleg, C., Kaouachi, N., Khelifi N., Menasria, A., \& Bensoullah, M. 2018. Feeding Habits of Cyprinus carpio in Foum ElKhanga Dam, SoukAhras, Algeria. AACL Bioflux, 11(2):554-564.

Shafi, S., Bhat, F. A., Yousuf, A. R., Parveen, M., 2012 Biology of Cyprinus carpio communis from Dal Lake, Kashmir with Reference to Food and Feeding Habits, Length-Weight Relationship, and Fecundity. Nature Environment and Pollution Technology. An International Quarterly Scientific Journal, 11(1):79-87.

Sheetal, L. \& Shate T.V. 2015. Feeding Potential of Cyprinus carpio L. and Labeo Rohita Ham. on Culex larvae (diptera:culicidae). Indian Journal of Applied Research, 5(9):464-465.

Sanyal, S. \& Ghosh, S. 2014. Prey Selectivity and Efficient Biocontrol of Dengue by Guppies : Effects of Alternative Prey and Habitat Complexity. International Journal of Pure and Applied Zoology, 2(4):339-347.

Sritabutra, D., Soonwera, M. 2013. Repellent Activity of Herbal Essential Oils Against Aedes aegypti (Linn.) and Culex quinquefasciatus (Say.). Asian Pac J Trop Dis, 3(4):271-276.

Trewin, B.J., Darbro, J.M., Jansen, C.C., Schellhorn, N.A., Zalucki, M.P., Hurst, T.P., Devine, G.J. 2017. The Elimination of The Dengue Vector, Aedes aegypti, from Brisbane, Australia: The Role of Surveillance, Larval Habitat Removal and Policy. PLoS Negl Trop Dis, 11(8):e0005848.

Vinson, M.R. \&Angradi, T.R. 2011. Stomach Emptiness in Fishes: Sources of Variation and Study Design Implications. Rev Fish Sci, 19(2):63-73.

WHO [World Health Organization]. 2012. Global strategy for dengue prevention and control 2012-2020. France: World Health Organization. 